University at Buffalo School of Law

Digital Commons @ University at Buffalo School of Law

2006

\title{
Free Wage Labor and The Suffrage in Nineteenth Century England
}

Robert J. Steinfeld

University at Buffalo School of Law

Follow this and additional works at: https://digitalcommons.law.buffalo.edu/journal_articles

Part of the Labor and Employment Law Commons, and the Legal History Commons

\section{Recommended Citation}

Robert J. Steinfeld, Free Wage Labor and The Suffrage in Nineteenth Century England, 123 Z Savigny Stift Rechtsgesch Ger Abt 266 (2006).

Available at: https://digitalcommons.law.buffalo.edu/journal_articles/589

\section{C) ${ }_{\text {COPYRIGHT }}^{\text {N }}$}

This Article is brought to you for free and open access by the Faculty Scholarship at Digital Commons @ University at Buffalo School of Law. It has been accepted for inclusion in Journal Articles by an authorized administrator of Digital Commons @ University at Buffalo School of Law. For more information, please contact lawscholar@buffalo.edu. 


\title{
Free Wage Labor and The Suffrage in Nineteenth
}

\section{Century England}

\section{Steinfeld, Robert J.}

\author{
in: Zeitschrift der Savigny-Stiftung für \\ Rechtsgeschichte / Germanistische Abteilung |
}

\section{Zeitschrift d...}

17 Seite $(n)([267]-283)$

\section{Nutzungsbedingungen}

DigiZeitschriften e.V. gewährt ein nicht exklusives, nicht übertragbares, persönliches und beschränktes Recht auf Nutzung dieses Dokuments. Dieses Dokument ist ausschließlich für den persönlichen, nicht kommerziellen Gebrauch bestimmt. Das Copyright bleibt bei den Herausgebern oder sonstigen Rechteinhabern. Als Nutzer sind Sie sind nicht dazu berechtigt, eine Lizenz zu übertragen, zu transferieren oder an Dritte weiter zu geben.

Die Nutzung stellt keine Übertragung des Eigentumsrechts an diesem Dokument dar und gilt vorbehaltlich der folgenden Einschränkungen:

Sie müssen auf sämtlichen Kopien dieses Dokuments alle Urheberrechtshinweise und sonstigen Hinweise auf gesetzlichen Schutz beibehalten; und Sie dürfen dieses Dokument nicht in irgend einer Weise abändern, noch dürfen Sie dieses Dokument für öffentliche oder kommerzielle Zwecke vervielfältigen, öffentlich ausstellen, aufführen, vertreiben oder anderweitig nutzen; es sei denn, es liegt Ihnen eine schriftliche Genehmigung von DigiZeitschriften e.V. und vom Herausgeber oder sonstigen Rechteinhaber vor.

Mit dem Gebrauch von DigiZeitschriften e.V. und der Verwendung dieses Dokuments erkennen Sie die Nutzungsbedingungen an.

\section{Terms of use}

DigiZeitschriften e.V. grants the non-exclusive, non-transferable, personal and restricted right of using this document. This document is intended for the personal, non-commercial use. The copyright belongs to the publisher or to other copyright holders. You do not have the right to transfer a licence or to give it to a third party.

Use does not represent a transfer of the copyright of this document, and the following restrictions apply:

You must abide by all notices of copyright or other legal protection for all copies taken from this document; and You may not change this document in any way, nor may you duplicate, exhibit, display, distribute or use this document for public or commercial reasons unless you have the written permission of DigiZeitschriften e.V. and the publisher or other copyright holders.

By using DigiZeitschriften e.V. and this document you agree to the conditions of use.

\author{
Kontakt / Contact \\ DigiZeitschriften e.V. \\ Papendiek 14 \\ 37073 Goettingen \\ Email: info@digizeitschriften.de
}




$$
\text { 管Zeit }
$$




\title{
Free Wage Labor and The Suffrage in Nineteenth Century England
}

\author{
Von
}

Robert J. Steinfeld

\begin{abstract}
Summary: 1. Introduction: Conflicting Historical Narratives; 2. Penal Enforcement of Wage Labor Agreements in Nineteenth Century England; 3. The Economics of Coercion In Wage Labor; 4. The Importance of An Expanded Suffrage In Ending The Use of Penal Pressure In Wage Labor; 5. Conclusion: Free Markets and Free Wage Labor?

1. Introduction: Conflicting Historical Narratives:

Over recent decades the master historical narrative of modern slavery has largely been rewritten'). Today, most historians accept the idea that modern slavery did not disappear because physical coercion proved unprofitable in extracting slave labor services ${ }^{2}$ ). They believe that slavery disappeared because states compelled employers of slave labor to give up the practice, even while it continued to generate large profits. Yet while the master historical narrative of slavery has been largely rewritten, the same cannot be said about the master historical narrative of wage labor. Surprisingly, the latter narrative continues to rely on the traditional notion that Anglo-American waged labor over the last few centuries was free labor because employers shunned physical coercion as an unprofitable method for extracting labor services. The underlying economic logic of the free wage labor narrative is the same logic that has been discredited as a basis for understanding the history of modern slavery. Yet, while the slavery narrative has been transformed, the traditional free wage labor narrative endures.
\end{abstract}

1) Time On The Cross: The Economics of American Negro Slavery (1974), by Robert Fogel and Stanley Engerman was the book that initiated this reappraisal.

$\left.{ }^{2}\right)$ See, for example, Ira Berlin, Many Thousands Gone (1998), and Philip Morgan, Slave Counterpoint (1998).

$19 *$ 
The dominant view among historians continues to be that waged labor has been free labor in England and America at least since the eighteenth century simply because the market, rather than other more direct means of coercion, completely satisfied the economic needs of employers. Depending upon one's political perspective, market incentives or market pressures are thought to have worked perfectly well to supply employers with cheap, efficient wage labor. Indeed, bodily compulsion ${ }^{3}$ ) is assumed to have been costly and to have produced sullen, inefficient workers. The free labor narrative with its underlying assumption about the economic inefficiency of bodily coercion has a long history, dating back in its modern form to the eighteenth century $\left.{ }^{4}\right)$. During the last decade of that century, for example, Joseph Townsend wrote that

Legal constraint is attended with much trouble, violence and noise; creates ill will, and never can be productive of good and acceptable service; whereas hunger is not only peaceable, silent, unremitting pressure, but, as the most natural motive to industry and labor, it calls forth the most powerful exertions; ... The slave must be compelled to work but the free man should be left to his own judgment and discretion; should be protected in the full enjoyment of his own, be it much or little; and punished when he invades his neighbor's property ${ }^{5}$ ).

During the same period in which Townsend wrote, Adam Smith offered a more positive version of the factors that made free labor more efficient that coerced labor. Coercion, he argued, gave workers little incentive to produce efficiently. "Whatever work [a slave does] can be squeezed out of him by violence only, and not by any interest of his own"'). By contrast free workers have "a plain interest that the whole produce should be as great as possible, in order that their own proportion may be so"'). Even today such views carry great weight. Recently, for example, one survey of economic literature observed that "[e]lementary economic reasoning suggests that in the long run

${ }^{3}$ ) By bodily compulsion, I mean compulsion that involves physical violence, bodily confinement, loss of bodily freedom of movement, or threats of such consequences. I contrast bodily compulsion, for the purpose of the argument here, to economic or pecuniary compulsion that involves deprivation of property or income. For a fuller discussion of this issue, see R obert Steinfeld, Coercion, Contract and Free Labor (2001), 1-29, 308-311.

$\left.{ }^{4}\right)$ A. W. Coats, "Changing Attitudes to Labour in the Mid-Eighteenth Century," Economic History Review, $2^{\text {nd }}$ ser., XI (1958).

5) Joseph Townsend, "A Dissertation on the Poor Laws" quoted in David Brion Davis, The Problem of Slavery in the Age of Revolution, 1770-1823 (1975), 358-59.

$\left.{ }^{6}\right)$ Adam Smith, Wealth of Nations (Edwn Cannan, ed., 1976), Book III, Ch. II, 411-412.

7) Ibid., p. 413. 
the institution of slavery is unviable economically ... As a slave receives only a fraction of his marginal product, enough to cover productive consumption, he has fewer incentives to work hard than if he were to internalize his entire marginal product as free workers do" $)$.

Modern historians have produced additional arguments showing that uncoerced labor has proved to be economically superior to coerced labor. A number of American historians, for example, have argued that American employers spontaneously turned away from indentured servitude and toward free wage labor during the late eighteenth century because they found indentured labor more costly than free labor, since it committed them to support their indentured workers during increasingly common economic downturns ${ }^{9}$ ). Another historian has argued that bound labor was abolished in the Scottish coal mines during the last quarter of the eighteenth century because powerful mine owners wished to gain unimpeded access to the limited pool of skilled Scottish coal miners, and agitated for the abolition of bound labor in order to do so ${ }^{10}$ ).

The dominance of this kind of reasoning has left historians with little motive to look for examples of the use of bodily coercion in the history of wage labor. And by and large historians have not found what they did not go looking for. The historical picture of wage labor today takes for granted, in the main, that wage work has not traditionally been subject to direct forms of coercion, indeed it is almost considered a contradiction in terms to think that it could have been.

What is strange about the enduring power of this wage labor narrative is that historians of slavery no longer accept the proposition, by and large, that bodily coercion cannot produce highly productive labor. On the contrary, historians of modern slavery are now widely agreed that bodily coercion, or bodily coercion combined with incentives, did produce labor that was even more productive than wage labor in certain settings, and in other settings, urban artisanal work for example, at least as productive as waged labor.

To be sure, over the last 25 years there has been a general reassessment of the efficacy of coercion in labor relations, and historians have discovered

$\left.{ }^{8}\right)$ Thrainn Eggertsson, Economic Behavior and Institutions (1990), 205.

9) Sharon Salinger, 'To Serve Well and Faithfully,' Labor and Indentured Servants in Pennsylvania, 1682-1800 (1987), 149-52; Gary Nash, The Urban Crucible (1979), 320.

10) Christopher Whatley, “'The Fettering Bonds of Brotherhood': Combination and Labour Relations in the Scottish Coal-Mining Industry, c. 1690-1775", Social History 12 (May, 1987). 
much more coerced labor in the world than they had previously thought existed. That bodily coercion cannot produce highly productive, profitable labor is no longer accepted as a universal rule of labor relations. But historians have been reluctant to embrace the opposite proposition, that bodily coercion might have been economically advantageous for employers in a wide variety of labor market settings. Instead, they have strained to define precisely those market conditions under which bodily coercion could prove economically advantageous, and to distinguish them from the more typical market conditions under which employers would not have found bodily coercion beneficial").

This is a complicated story, but in general a tacit consensus has emerged that in places in which labor was relatively abundant, as in the fully developed wage labor markets of the metropolitan core of England and the United States, bodily coercion was economically unnecessary, indeed even counterproductive. As a result coerced labor has come to be viewed mainly as a phenomenon of the global periphery (where labor markets were thin), and of certain forms of agricultural production (in which working conditions were particularly onerous). For all the progress that has been made in understanding how widely coerced labor was used, the view that bodily coercion can be of great benefit in extracting labor services has not generally been seen to apply to the case of wage labor in the English and American metropolitan core.

2. Penal Enforcement of Wage Labor Agreements in Nineteenth Century England:

The narrative of free wage labor endures, by and large, despite the fact that as long ago as 1954 Daphne Simon demonstrated unequivocally that penal pressure was, in fact, used quite widely against wage workers in nineteenth England ${ }^{12}$ ). One would have thought the rediscovery that under the English Master and Servant acts wage workers had regularly been imprisoned at hard labor for violating their work agreements, in the nation that stood at the forefront of free market industrialization, might have led to a rethinking of the master historical narrative of wage labor $\left.{ }^{13}\right)$. But it did not. And one important reason it did not was that Simon herself interpreted the English practice

11) For one of the best attempts to identify these different labor market conditions see Evsey Domar, "The Causes of Slavery or Serfdom: A Hypothesis", Journal of Economic History 30 (March, 1970).

$\left.{ }^{12}\right)$ Daphne Simon, "Master and Servant", in Democracy and the Labour Movement: Essays in Honour of Dona Torr (John Saville, ed., 1954).

$\left.{ }^{13}\right) 4 \mathrm{Geo}$. IV, c. 34 (1823). Most skilled English workers were not employees at will, but served under agreements that bound them for shorter or longer terms of service or called for them to give several weeks or a month's notice before leaving. 
through the lens of a Marxist version of the free wage labor narrative. She subscribed to the view that modern capitalism relied on the dull compulsion of economic relations to extract labor services. Other forms of coercion like the penal coercion authorized by the Master and Servant acts were relics of a feudal stage of development, and doomed to extinction because they no longer served the economic interests of modern capitalist employers. She thought that the Master and Servant acts might have been of some help to small, backward employers, but as the economy modernized the acts became less and less useful. As soon as organized labor began to protest, she argued, the employing classes simply abandoned the acts, putting up only symbolic resistance. Thus Simon, who was the first to rediscover how extensively penal pressure had been used in English wage labor as late as 1875, dismissed its economic importance, relegating it to a marginal role in the history of wage labor.

A second important reason her discovery had practically no impact on the larger historical narrative of wage labor was that no one seemed able to say precisely what economic benefits employers derived by using penal pressures against wage workers. And without such an explanation, there was no basis for calling into question the economic logic upon which the free labor narrative rested: wage labor has been free labor simply because employers found bodily coercion unprofitable. Yet the stubborn fact remained that in the years between 1857 and 1875 (years for which there are comprehensive statistics available) English employers frequently used penal pressure against their wage workers. About 10,000 English workers each year on average were prosecuted for misbehavior at work, or for leaving work before their agreement entitled them to $\left.{ }^{14}\right)$. Until 1867 , about 1,500 workers, on average, were imprisoned each year, but a large percentage of the 10,000 or so workers who were prosecuted each year, but not imprisoned, were forced back to work under the threat of imprisonment ${ }^{15}$ ).

Recently, historians have begun to devote more attention to the Master and Servant acts. A number of new studies of the acts have now been published, and a consensus has emerged that Simon's view that the acts were economically anachronistic is simply wrong ${ }^{16}$ ). But none of these studies has managed

$\left.{ }^{14}\right)$ Judicial Statistics, England and Wales, 1857-1875, 19 vols. (1858-1876) and Simon, "Master and Servant," op. cit. n. 12.

${ }^{15}$ ) "In one small sample from Preston and surrounding towns in Lancashire during 1865-66, I've found that $54 \%$ of those prosecuted were ordered back to work under threat of imprisonment, while only $17 \%$ of those prosecuted were actually given a prison term" (Marc W. Steinberg, unpublished manuscript in author's possession).

${ }^{16}$ ) See, for example, Douglas Hay, "Penal Sanctions, Masters and Servants" (Un- 
to identify precisely what economic benefits employers derived by using penal pressure against wage workers. As a result, even though the widespread use of penal pressure in English wage labor is now well documented, there has been no direct challenge to the economic logic that underlies the larger free wage labor narrative.

As a result historians today subscribe to two master historical narratives of labor based on contradictory views about the economic efficacy of bodily coercion. The slavery narrative is based on the idea that bodily coercion of labor was of great economic benefit to employers, and that they relinquished it only when the state, for political and moral reasons, compelled them to do so. The other narrative, the wage labor narrative, holds just the opposite, that bodily coercion of labor produced sullen, inefficient workers, and employers of waged labor avoided using it. According to this narrative, free wage labor was the spontaneous result of the operation of employer interests in free markets, rather than a product of political intervention.

But by now it is clear that the traditional wage labor narrative does not fit the facts very well. In particular, it does not account for what we know about the widespread use of penal pressure in nineteenth century English wage labor. Nevertheless, if this long established narrative is to be definitively overturned, it is necessary to show that its economic rationale is flawed. It is necessary to demonstrate that employers of waged labor derived real economic benefits by using penal pressure in a variety of market settings. If this can be shown, then factors other than the economic interests of employers must have been responsible for the ultimate disappearance of this type of coercive power over wage labor. Such a demonstration opens up the possibility, moreover, that, as in the case of slavery, state intervention, rather than market forces, led to the elimination of an otherwise profitable form of coercive power.

3. The Economics of Coercion In Wage Labor:

Transaction costs analysis, developed in recent decades by neo-institutional economists, helps to identify precisely what economic benefits employers of waged labor derived from the use of penal pressure. This analysis must begin with wages. Institutional economists have shown that neither hourly wages nor piece-work wages completely eliminates the need for supervision (and hence supervision costs) in waged labor. Employers of waged labor face su-

published manuscript, 1990); and Hay, "Masters, Servants, Justices and Judges" (Unpublished manuscript,1988); D. C. Wood s, "The Operation of the Master and Servants Act in the Black Country, 1858-1875," Midland History 7 (1982). 
pervision problems that are not completely unlike those faced by slave owners. "Owners had the choice," Yoram Barzel writes, "between supervising their slaves' output [as to quantity and quality], which is comparable to what employers have to do when the free workers they employ work by the piece, and supervising their effort, which is comparable to what employers have to do when they employ free workers by the hour"1'). Because the interests of waged workers cannot be perfectly aligned with the interests of their employers through the payment of wages, employers inevitably incur supervision costs in the course of production.

These costs are of two kinds, costs of supervision to enforce effort or guarantee quality, and residual costs of reduced output or low quality that cannot be eliminated because the added costs of supervision necessary to eliminate them will be higher than the improvement in quality and increase in production such increased supervision can be expected to generate. Threats of dismissal can certainly raise the costs of shirking to workers, and may help to control supervision costs, but dismissal is not always a good option for employers. Where waged labor is skilled and labor markets are tight, the threat of dismissal loses much of its power.

Unemployment among skilled workers in England has been estimated to have been below $4 \%$ in 11 of the 15 years between 1860 and $1875^{18}$ ). But where sloppiness or loafing at work can lead to a prison term at hard labor, through the use of an inexpensive, summary legal process, the prospect of incarceration at hard labor must certainly raise the expected cost of shirking to workers, at little additional cost to employers, yielding both less shirking and lower supervision costs. At a time when supervision strategies in many industries were not well developed, these advantages were probably substantial.

There are numerous examples in the records of English employers prosecuting workers because they failed to work as well or as hard as was expected. "George Heywood of West Bromwich", for example, was a bundler at the furnace of an iron works with both puddlers and millmen dependent upon him. Because he left his labour for a few hours, "the work was very much in arrears and other men were idle." He was given the option of paying $£ 5$ damages or having two months in prison and remarked that "he would have to have the two months"19).

${ }^{17}$ ) Yoram Barzel, Economic Analysis of Property Rights (1989), 80.

${ }^{18}$ ) William Beveridge, Full Employment in a Free Society, 2d ed. (London 1960), Appendix A; see also A. C. Pigou, Industrial Fluctuations, 2d ed. (London 1929), Appendix, Table 1.

$\left.{ }^{19}\right)$ D. C. Woods, "The Operation of the Master and Servants Act in the Black Country," 105. 
A puddler working the night shift at an iron works in Walsall, Staffordshire left iron in the furnace overnight where it spoiled, causing his employer substantial damage. He was given a twenty-one day sentence ${ }^{20}$ ). George Odger, a bootmaker in the putting out system testified in the 1860 s that

Any decent man ... is apt to be terrified with the thought that his employer would feel disposed to have him before a magistrate for [a] breach of contract ... I think it would be about two months ago ... I went over the time [for returning finished work], the first time I ever did in my life; [my employer] called at my house when I was out and threatened that if he had not the work in a given time he would proceed against me in the ordinary way for breach of contract. I went home and then went to the workshop and worked nearly all night to get the work to him the next day, which embarrassed me a good deal because I had been at work all the day before. I do not know whether he would have carried out his threat or not, but I was within his clutches if I did not make the boots ${ }^{21}$ ).

A summary criminal penalty for breaches of labor agreements also helped employers to lower other types of costs. Turnover costs are the costs an employer must bear when a worker leaves his job. One of the most significant elements of turnover costs is often the cost of lost output between the departure of a worker and his subsequent replacement. But an employer must also frequently bear search costs and training costs. Turnover is far from costless in the case of skilled labor, even in thick labor markets, and may be especially high when labor markets are tight. In England in the years between 1857 and 1875, employers prosecuted workers under the Master and Servant acts much more frequently when unemployment was low than when it was high, and as noted, unemployment was often very low in this period ${ }^{22}$ ). There is abundant evidence from the period that employers commonly used contracts of a fortnight or a month to regulate turnover, to prevent workers from leaving suddenly, possibly disrupting production, and to give themselves time to locate replacement workers. If a worker was not free to leave immediately but was required to give two weeks' or a month's notice, by the time he was free to leave other offers of employment might no longer remain open and in those cases turnover costs might be avoided altogether.

In addition, a well timed policy of signing skilled workers to criminally enforceable labor contracts of a year or several years, which employers commonly did during this period, might have helped to lower labor costs in yet

\footnotetext{
20) Ibid.

$\left.{ }^{21}\right)$ Testimony of George Odger before the "Select Committee on Master and Servant" (1866), XIII, Q. 1813.

$\left.{ }^{22}\right)$ Robert Steinfeld, Coercion, Contract and Free Labor in the Nineteenth Century (2001), 75-77.
} 
another way, by slowing the rate of wage increases during periods of low unemployment. Workers bound by a criminally enforceable contract were obligated to work for the wages they had originally agreed upon, even if in a tight labor market wages subsequently rose. Unemployment was extremely low in 1864 and 1865, for example, and employers in the pottery trade began to try to impose annual contracts on their workmen. One potter complained that "seeing that trade is now in a prosperous state, that long period of agreement takes from the workman the power of raising the price of his labour" ${ }^{23}$ ). In June, 1865 a worker named Clarke signed a two year contract to work for a cutlery manufacturer. In November, Clarke left and Unwin, his employer, prosecuted him for contract breach. Clarke answered that "he had applied to [his employer] to make an advance in his wages in the same manner that the large majority of the cutlery manufacturers in Sheffield had recently done to their hired workmen, which the appellants had refused to do, and in consequence thereof he had felt himself justified in refusing to work for them at the low rate of wages" ${ }^{24}$ ). In 1865 skilled unemployment hovered around $2 \%{ }^{25}$ ). The magistrates warned Clarke that the contract prices could not be raised except by mutual consent, that Unwin was unwilling to agree to an increase, and that Clarke must return to work at the old prices or be imprisoned. Clarke answered that he would rather be sent to prison than go back to work at the original prices. The justices obliged, sentencing Clarke to 21 days at hard labor. When he was released, he returned to Unwin to retrieve his tools, but Unwin insisted that Clarke was still obligated to work out his contract at the original prices. Clarke refused and was prosecuted again. The court ruled that he could be imprisoned a second time, and at this point Clarke had had enough, deciding to return to work on the original terms $\mathrm{s}^{26}$ ).

It is true that there were disadvantages as well as advantages for employers in this system of criminally enforceable labor contracts. In tight labor markets the system might make it more difficult for an employer to obtain skilled labor. In slack labor markets he might have to worry about contractual obligations he had undertaken in more prosperous times. But taken all together employers derived considerable economic benefits from their power

$\left.{ }^{23}\right)$ "Select Committee on Master and Servant" (1866) XIII, Q. 1410.

${ }^{24}$ ) Unwin v. Clarke, 1 L.R. 417 (1866), 418.

${ }^{25)}$ For estimates of skilled unemployment rates, see Beveridge, Full Employment in a Free Society, Appendix A; and Pigou, Industrial Fluctuations, Appendix, Table 1.

${ }^{26}$ ) Unwin v. Clarke, 1 L.R. 417 (1866), 418-19; and testimony of William Dronfield before the "Select Committee on Master and Servant" (1866), XIII: Q. 864. 
criminally to enforce the performance of labor agreements of various lengths under which almost all skilled English workers were employed.

The economic benefits of penal coercion explain why employers continued to prosecute workers under the Master and Servant acts with great enthusiasm up until almost the moment the acts were repealed. In 1871 unemployment among skilled workers fell to $1.6 \%$, in 1872 to $.9 \%$. In 1873 it rose slightly to $1.2 \%$ and in 1874 to $1.7 \%{ }^{27}$ ). In 1870 employers prosecuted 8,670 workers in England and Wales for offences under the Master and Servant acts. In 1871, however, as unemployment plunged, they prosecuted 10,810 workers, and in 1872 prosecutions soared to 17,082 and then came down slightly in 1873 to 16,230 . But in 1875, the very year the Master and Servant acts were repealed, prosecutions were still at a level of $14,353^{28}$ ).

The economic benefits employers derived from using penal pressure also help to explain why ruling elites did not give up the Master and Servant Acts without a very long struggle. It took organized British labor almost 15 years of campaigning before Parliament finally repealed the acts, and over this period the system of penal coercion continued to be defended tenaciously. Concessions were made only grudgingly, and a great deal of effort was expended to preserve the core practices of the old system for as long as possible ${ }^{29}$ ). English

${ }^{27}$ ) Beveridge and Pigou, op. cit.

${ }^{28}$ ) Judicial Statistics, England and Wales, 1857-1875, 19 vols. (1858-1876). These are large numbers but they represent only a small percentage of the laboring population as a whole, and the question inevitably arises whether the acts were actually effective in accomplishing their goals. We probably can never have a definitive answer for this question, because on the one hand it is impossible to determine how often workers violated labor agreements and were not prosecuted, and on the other how often workers thought about but did not violate labor agreements because they feared prosecution. These everyday events would not have shown up in prosecution statistics. For an extended discussion of this problem, see Steinfeld, Coercion, Contract and Free Labor, 72-82. But we do have some evidence and it is possible to make some guesses about the effectiveness of the acts. One Justice of the Peace, who was also an employer, when asked whether he had resorted to the acts very often answered "No, not often ... The moral effect of having the power is often sufficient." Testimony befor the Select Committee on Master and Servant (1866), XIII,Q.1441. We also know that local newspapers throughout the country reported Master and Servant prosecutions in their daily or weekly crime columns so that local workmen would have been put on notice as to who and how many local workers were being made examples of. At the very least, the acts loomed large enough in the lives of working people to induce them to undertake an extended political campaign to have them reformed.

${ }^{29}$ ) For an extended discussion of these parliamentary battles, see Steinfeld, Coercion, Contract and Free Labor, Ch. 6. 
employers clearly believed that they profited from the use of penal pressure in wage labor, used such pressure frequently in their dealings with wage workers, and resisted efforts to deprive them of the power. The ways in which penal pressure helped to lower supervision and turnover costs, and keep wages in check during periods when labor markets was tight, explain why employers would not have relinquished this power without a struggle. A clear economic logic existed for the retention of penal pressure in wage labor long after the advent of industrial capitalism.

In the traditional narrative of free wage labor, employer interests explain the supposed absence of bodily coercion in wage labor. But it is now clear not only that English employers continued to utilize penal pressure during industrialization, but that they did so precisely because they found it profitable. In fact, English employers did not abandon penal pressure as a natural consequence of the introduction of freer markets in the nineteenth century. They were compelled to relinquish it by a political act of the state. In 1875 , Parliament repealed the Master and Servant acts, stripping employers of the power to use penal pressure. But employers continued to use penal pressure against wage workers up until the very moment the acts expired.

4. The Importance of An Expanded Suffrage In Ending The Use of Penal Pressure In Wage Labor:

It is necessary at this point in the argument to address the question of causation. How was it possible for such a fundamental change in the legal rules governing wage labor to have been adopted over the objections and in opposition to the economic interests of employers? The answer is a complicated one, but it is to be found in the realm of political struggle.

In 1867 Parliament passed the Second Reform Act, which greatly expanded the British suffrage. In the United Kingdom as a whole the number of people enfranchised nearly doubled, from about 1.3 million to about 2.4 million $^{30}$ ). In many towns the new suffrage gave artisans and laborers a majority of the vote $^{31}$ ).

Whatever meaning is attached to the phrase 'working-class', the potential working-class electorate in English and Welsh boroughs in the period immediately after 1867 was probably about five times the size of the working-class electorate in these boroughs before, and over a half their total electorate ${ }^{32}$ ).

$\left.{ }^{30}\right)$ F. B. S mith, The Making of the Second Reform Bill (1966), 236.

$\left.{ }^{31}\right)$ R. K. Webb, Modern England (New York, 1970), 326; Smith, Second Reform Bill, 225.

${ }^{32}$ ) Maurice Cowling, 1867, Disraeli, Gladstone and Revolution: The Passing of the Second Reform Bill (1967), 46. 
The expanded suffrage played a critical role in the repeal of the Master and Servant Acts in 1875, and with them, in the elimination of the power of employers to utilize penal pressure against wage workers. But before discussing the role an expanded suffrage played in producing this change in the basic terms of waged labor, it is necessary to say something about why ruling elites would have expanded the suffrage in the first place.

The best modern authorities reject the Whig interpretation of the passage of suffrage reform. Neither free market industrialization nor liberal ideas led inevitably to an expanded electorate.

[Whig historians] see industrial change on the one hand and political change on the other, and assume a simple, one-way relationship between them. They by-pass, ignore or explain away both the hostility to change and the power to resist it which analysis of society at large suggests might be found, not just on one side of the House of Commons but in most parts of both.

They assume, moreover, a straight progression from the reforms of the 1830 s to the reforms of the 1870 s, neglecting the recession in progressive feeling ... The death of Chartism, the mid-Victorian boom and the hints given, alongside a militant trade unionism, of a contented, loyal and royalist working class in some of the larger cities, produced a sense of political stability and distrust of Radical motion which impregnated the social attitude of a great part of the House of Commons. If the Reform bill of 1867 symbolized the beginning of a period of rapid political change, it did so in a parliament which not only thought of itself as the ruling assembly of a highly stable society but was also in strong reaction against any suggestion that it should be otherwise $^{33}$ ).

During the 1850 s and early 1860 s a number of attempts to pass suffrage reform had failed to make any headway in Parliament. Indeed, just a year earlier, in 1866, a much less radical suffrage reform bill, brought to the floor by Gladstone and the Liberal Party, went down to defeat in Parliament ${ }^{34}$ ). Ultimately, what led to electoral reform in 1867 was a combination of factors, the most important of which seem to have been the widespread desire among ruling elites to reach a limited political settlement with the increasingly well organized and restive working classes, and a political competition between Gladstone and Disraeli and the Liberal and Conservative Parties for electoral advantage in the near term future $\left.{ }^{35}\right)$. The Reform Bill of 1867 was brought forward and passed by a Conservative government. While it cannot be said that the working classes actually forced reform upon Parliament, it is nevertheless the case that as a result of the defeat of the Liberal suffrage reform bill in 1866, trade unionists and middle class radicals launched and

\footnotetext{
${ }^{33}$ ) Ibid., 1-2.

${ }^{34}$ ) Smith, Second Reform Bill, 110.

${ }^{35}$ ) Ibid., 229.
} 
sustained an out of doors agitation for suffrage reform that lasted nearly a year until "the borough suffrage provisions of the [original] Conservative Bill were transformed and safe" ${ }^{{ }^{36} 6}$ ). During this long period mass demonstrations were held in nearly every major English city sometimes drawing as many as 150,000 people $^{37}$ ).

The expansion of voting rights played a critical role in the parliamentary deliberations that led to the elimination of penal coercion in English wage labor. It is possible to assess the impact of the expansion of the suffrage by comparing the very different results achieved by two different attempts to reform the Master and Servant acts that were undertaken within a few years of each other, one before suffrage reform, the second after.

In the early 1860 s trade unionists launched a campaign to reform the Master and Servant acts. In 1867, almost at the same time that the suffrage Reform Bill was making its way through Parliament, Parliament was also considering reforms of the Master and Servant acts. In August of that year Parliament did pass a Master and Servant reform act. But this first reform act was passed by a Parliament that had been elected under the old, unreformed suffrage, and it failed to free working people from the penal pressures to which they had long been subject.

Lord Elcho, a conservative Whig, introduced the bill that ultimately became the first Master and Servant reform act. In 1866 Elcho had voted against Gladstone's suffrage reform bill because he thought that it did not go far enough to secure a durable political settlement with the working classes, one that would guarantee social and economic peace. Thinking that the Conservatives would reward him for his role in Gladstone's defeat, he pressed the new Conservative government in 1867 to bring forward a reform bill for the Master and Servant acts. But the government refused and Elcho, thinking that reform of these acts was essential if social peace was to be maintained, introduced his own member's bill.

The previous session Elcho had chaired a parliamentary committee charged with studying the issue of the Master and Servant acts. He had been chosen in part because of his long relationship with trade unionists. An old fashioned paternalist, he hoped to introduce just enough reform to stabilize old hierarchies. The trade union agitation of the previous years had convinced him that it was essential to reform the Master and Servant acts, and his bill went some distance toward meeting the complaints of organized labor.

\footnotetext{
36) Ibid.

${ }^{37}$ ) Ibid., 139-140.
} 
Their chief complaint was that criminal compulsion violated the liberal principle of equal treatment under law. Employers were not subject to criminal penalties under the Master and Servants acts for breaches of labor agreements on their side, only workers were subject to such sanctions. Moreover, trade unionists contended, penal sanctions to enforce private agreements represented a total anomaly in contract law. Breach of contract normally only gave rise to a civil action for damages. Hence, the Master and Servant acts represented an intolerable example of class legislation.

Elcho's bill attempted to address several of these objections by making proceedings under the Master and Servant law as nearly civil in nature as seemed politically possible under the circumstances. In an apparent effort to preserve the civil nature of proceedings under a new Master and Servant act, Elcho's bill established an entirely separate procedure for criminal prosecutions and indicated that such prosecutions should only be based on acts that were already criminal under the general criminal law. Nevertheless, from a modern perspective, Elcho's bill was far from ideal. It continued to give employers the power to seek specific performance of labor agreements (a civil remedy), and it by no means entirely abolished the possibility of criminal prosecution for contract breach.

Nevertheless, when the Elcho bill was introduced into Parliament, it ran into stiff resistance. Most of the members who spoke thought that reform of Master and Servant law was necessary but that Elcho's bill went too far. Mr. Alderman Salomons, for example, said that

he must express his approval of the Bill. It was founded on reciprocity of principle between master and servant. By the present law, the master was responsible civilly-the servant criminally. [Nevertheless][i]n all cases where, by the Act of the servant, any injury was inflicted upon the master which could not be compensated by fine, an option of imprisonment ... ought still to be left ${ }^{38}$ ).

A smaller group in parliament spoke against even the principle of reform. Mr. Liddell said that he

could not agree that the House would do well to adopt the whole principle of the present Bill. That principle was the abandonment of the punitive process against the workmen and the doing away with the deterrent effect of the present law $w^{39}$ ).

Mr. Jackson added,

Was a man, having charge of an engine at a pit's mouth, who got drunk and ran away to be dealt with merely as a debtor, though he might leave 400 or 500 fellow workmen below in enforced idleness and in cruel uncertainty for six or seven hours? It was the

${ }^{38}$ ) Debate over Lord Elcho's bill, June 4, 1867 Hansard's Parl. Debates (1867), CLXXXVII, col. 1607.

${ }^{39}$ ) Ibid., col. 1606. 
knowledge that under the existing law he would be dealt with very differently which kept such a man from getting drunk and running away ${ }^{40}$ ).

The weight of opinion in Parliament seems to have been that the principle that masters and men stood on a plane of equality should be conceded, but that the details of any new legislation must preserve as much of the old penal system as possible. Lord Elcho's bill was heavily amended in the course of Parliamentary deliberations. When it emerged from committee and was enacted into law as the 1867 Master and Servant reform act, the new act retained much more of the old penal law than had Lord Elcho's original bill. Employers could still seek immediate imprisonment for "aggravated" breaches of contract, and for "ordinary" breaches of contract, employers could now seek an order requiring a worker to return to work to perform his agreement. Given that employers had traditionally used the Master and Servant acts to force workers back to work more often than to imprison them, this was not a large concession ${ }^{41}$ ).

Just eight years later, in 1875, a Conservative government introduced a new bill to reform Master and Servant law, and in a Parliament elected under the expanded suffrage, the bill received an entirely different reception than had Lord Elcho's bill in 1867. Following suffrage reform, labor had begun to take a more active role in electoral politics. For a number of reasons trade unionists had grown deeply disaffected with the Liberal government by the time the general election of 1874 was called. During the election campaign Conservative candidates played to this antipathy in an effort to win over newly enfranchised workers $^{42}$ ). The results of the election of 1874 were somewhat of a surprise, the Conservatives won by a wide margin, and one factor in their victory seems to have been the active hostility of organized labor toward the Liberal Party ${ }^{43}$ ). It was to redeem electoral pledges to labor that the Conservative government introduced its bill to further reform Master and Servant law in 1875.

The Conservative bill was similar in its terms to the bill Lord Elcho had originally introduced in 1867 and which for all its limitations had been rejected by Parliament as too radical. In 1875, however, the dominant reaction in Parliament was just the opposite, the government bill failed to go far enough. Apparently, once the Conservative government made the decision to place reform on the agenda, it set in motion a process that carried the bill

${ }^{40}$ ) Ibid., col. 1611.

${ }^{41}$ ) See note 15. Note 15 reports prosecutions that took place before the 1867 Master and Servant reform act was passed.

${ }^{42}$ ) Sidney and Beatrice Webb, The History of Trade Unionism (London 1920), 287.

${ }^{43}$ ) Ibid., 286, and Robert Blake, Disraeli (New York 1967), 536.

20 Zeitschrift fur Rechtsgeschichte. CXXIII. Germ. Abt. 
further and further along in the direction of totally abolishing penal sanctions for labor contract breaches.

Liberal members competed with Conservative members to outdo one another in currying favor with newly enfranchised working class voters. The Liberal member Robert Lowe, who in 1866 had played a large role in the defeat of Gladstone's bill to reform the suffrage, now objected that the government bill unjustifiably preserved a number of penal features of the old law. Lord Montagu joined Lowe in raising these objections. If an act is a crime, they argued, it should be a crime whether or not the person is under contract, and regardless of his status in life. Criminal law should impose broad legal duties. Making breach of a labor contract an element of a crime smacked of class legislation, singling workers out for degrading treatment just as in the past. Lord Montagu observed that

to break a civil contract was a civil act, and we had no right to inquire into intention. In the case of a minute contract [employment at will], a man at the pumping engine of a mine might walk away without notice, immense damage might be done to property, and yet the act would not be a criminal one. But if there was a contract for a week, the man who should do the same act would commit a crime ... [If an act is a crime it should be a crime regardless of whether the person is serving under a labor contract $]^{44}$ ).

In the course of Parliamentary deliberations the government bill was heavily amended pushing the resulting legislation further and further in the direction of totally eliminating the penal aspects of the old Master and Servant law. The Employers and Workmen Act of 1875 profoundly changed the terms of English waged labor, abolishing, for all practical purposes, the power of employers to use penal pressure to enforce labor agreements.

A widened suffrage, of course, was not the only factor in the passage of the 1875 act. The state of trade union organization, and labor's increasingly active participation in electoral politics also played roles. In addition, certain members of parliament had become increasingly concerned that workers would refuse to enter into any labor agreement other than employment at will unless the Master and Servant law was changed. Nevertheless, an expanded suffrage was the critical factor in this alteration of basic ground rules in English wage labor, ground rules that henceforth prohibited, for all intents and purposes, the use of penal pressure in wage labor.

5. Conclusion: Free Markets and Free Wage Labor?

This change in ground rules was the result of almost 15 years of political struggle by organized labor, a struggle that met with great resistance until

${ }^{44}$ ) Hansard's Parl. Debates (1875), CCXXV: col. 656 (June 28, 1875). 
almost the last moment. English ruling elites did not spontaneously abandon penal pressure because it was proving unprofitable. In 1875 employers prosecuted 14,353 workers for various offences under the old Master and Servant law just as the new law was about to take effect ${ }^{45}$ ). Employers continued to find penal pressure of great economic benefit until the very last, until Parliament compelled them to give it up as a result of the outcome of a complicated series of political struggles. The logic of the rejection of penal coercion in English wage labor was a political not an economic logic. And it was unequivocally not the spontaneous result of the introduction of free markets.

Much more research needs to be done to understand the terms and operation of other legal regimes that governed waged labor in other countries during the nineteenth century, but if it turns out that the English case was not atypical in making penal pressure available to employers, it may be that the logic underlying the history of waged labor will also turn out to be not so different from the logic underlying the history of modern slavery. In both cases, that is, employers of labor would appear to have found the use of bodily compulsion (of various degrees of severity) economically advantageous for extracting labor services in a wide variety of market settings, and actively utilized this type of pressure until states, for a variety of political, social or moral reasons, intervened to force them to relinquish it.

${ }^{45}$ ) See volumes cited in note 28. 